\title{
ASYMMETRIC EFFECTS OF TRADE OPENNESS ON ECONOMIC GROWTH IN SELECTED ASEAN COUNTRIES
}

\author{
Jaka Sriyana ${ }^{1}$, Akhsyim Afandi ${ }^{2}$
}

\footnotetext{
1 Islamic University of Indonesia, Faculty of Economics, Department of Economics, Indonesia, ORCID: 0000-00015675-4758, jakasriyana@uii.ac.id;

2 Islamic University of Indonesia, Faculty of Economics, Department of Economics, Indonesia, ORCID: 0000-00026440-7542, 923130101@uii.ac.id.
}

\begin{abstract}
In the growing of economic integration and international relations, the effect of trade openness on economic growth has become an important issue across countries. Following the economic integration, the world trading system has become progressive and competitive in recent years. Many countries generated their economic growth by attracting both foreign and domestic investments and expanding export production. In response to current challenges posed by the implementation of economic integration in the ASEAN region, it is important to conduct a study focusing on the impact of trade openness as well as other economic factors on economic growth. This research examines the effects of trade openness and other economic variables such as foreign direct investment, gross capital formation and human capital on economic growth in selected ASEAN countries.

Using long term annual data, the empirical NARDL models incorporate asymmetric effects of trade openness on economic growth in Indonesia, the Philippines, Thailand, and Singapore. While such effects for the case of Malaysia are symmetric both in the short and long-run models, the effects are asymmetric in the long run and symmetric in the short run for the Philippines. Thailand, and Singapore. The results are different for Indonesia where the impact of trade openness is asymmetric in the short run and symmetric in the long run. This paper highlights that trade openness has a net positive impact on economic growth only in the Philippines and Singapore. It implies that most of the other countries in that region have a challenge regarding the implementation of trade liberalization. This research also found that both foreign and domestic investments are important factors of economic growth in the ASEAN countries. Similarly, human capital is proven to be an important factor in economic growth. This paper contributes to the literature by providing a new insight that incorporates the asymmetric effects of trade openness on economic growth.
\end{abstract}

Keywords: Economic growth, trade openness, asymmetric effects, capital, NARDL.

JEL Classification: FO, F1, O24.

APA Style Citation: Sriyana, J., \& Afandi, A. (2020). Asymmetric Effects of Trade Openness on Economic Growth in Selected ASEAN Countries. E\&M Economics and Management, 23(2), 66-82. https://doi.org/10.15240/tul/001/2020-2-005

\section{Introduction}

International trade has played the role of engine of growth in many countries around the world. Export-import activities may affect the economy through some channels. First, it makes easier to access many commodities and services that lead to higher levels of income per capita and better living standards (Butkiewicz \& Yanikkaya,
2011). Second, international trade among countries might also generate capital formation as an important step to the production process in the economy. The effect of international trade on income and economic growth has been intensively discussed in some papers (Altaee \& Al-Jafari, 2014; Bajwa \& Siddiqi, 2011; Das \& Paul, 2011; Hassen, Anis, Taha, \& Yosra, 2013; 
Hye, Wizarat, \& Lau, 2016; Malefane, 2018). The vector error correction model (VECM. Over 100 developed and developing nations in Asia, Africa, and Latin America experienced the positive impact of international trade on the increase of their income per capita (Butkiewicz \& Yanikkaya, 2011). Therefore, eliminating trade barriers as an implementation of liberalization agreements is likely to boost the volume of international trade and promote economic growth rates. Likewise, developing countries that are more open to the world markets tend to have greater opportunities to access new products and services (Paudel, 2014). On the other hand, it is also argued that protectionism policies such as strategic and infant industries may be beneficial for domestic economic development (Taleb, 2018).

As the world economy gets more integrated, the world trading system is becoming more progressive and competitive. Through various trade agreements, tariffs and restrictions have been significantly reduced in most countries in the world. Many countries are trying to adopt outward-looking policies to promote growth by attracting foreign investment and expanding export production (Alvarado, Iñiguez, \& Ponce, 2017; Comes, Bunduchi, Vasile, \& Stefan, 2018; Nagyová, Horáková, Moroz, Horská, \& Poláková, 2018). The integration of countries into the world economy is found to be an important determinant of income and growth across countries (lyke, 2017). It is evidence that trade has promoted the efficient allocation of resources and enhanced competition both in domestic and international markets. Another advantage of international trade is that it could lead to optimizing production processes and developing new products. Because of the successes of emerging outward-looking countries, and the failures of inward-looking countries, it was widely accepted that trade openness favored economic growth (Malefane, 2018).

Owing to increased economic integration and international relations, the effect of trade openness on economic growth has become an important issue. Over the last decade, many studies have examined the impact of trade openness on economic growth in various region economies (lyke, 2017; Majeed, 2010; Malefane, 2018). Some of the existing studies support the proposition that trade openness has a positive impact on economic growth.
More specifically, all previous studies note that trade openness, which is measured by the volume of export and import, has encouraged economic growth across countries. However, the impact of trade openness on economic growth differs across countries where the lowermiddle income countries benefited more than other groups (Paudel, 2014). These findings recommend the governments should taking into account in making policy reforms on trade liberalization.

Since the early 1980 s, the member countries of the Association of Southeast Asian Nations (ASEAN) region have experienced high rates of economic growth. With the potential market size of about 640 million consumers, the regional economies have grown by an average of $5.3 \%$ annually since 2000 and achieved combined gross domestic product (GDP) of US\$ 2.8 trillion in 2017 (Sing, 2018). These countries have also welcomed and applied liberalization policy as well as adopted market-based policies since 1990. Through the establishment of the ASEAN Free Trade Area (AFTA) in the 1990 and the ASEAN Economic Community (AEC) in 2015 , all the ASEAN member countries have developed international trade integration. This integration has contributed to the substantial economic reform processes in several member countries (Maria, Urata, \& Intal, 2017). The $\mathrm{AEC}$ is the largest economic community zone in the developing world that will create a single market with the free movement of goods and services. The member of AEC countries committed to realize ten packages of the ASEAN Framework Agreements and to deliver the key initiatives of the ASEAN Single Window (ASW). At the end of 2018, the AEC has agreed the implementation of AEC Blueprint 2025 for about thirteen issues to boost trade activities among the member countries. Therefore, goods and services mobility, foreign direct investment, easier movement of capital and skilled labor will become key factors in achieving higher economic growth in this region (Maria et al., 2017).

No doubt, the implementation of the international trade integration in the ASEAN region has posed a new challenge to the member countries as to whether they can take the most benefits from it in terms of higher exports and imports among them and hence higher economic growth. Therefore, it is important to conduct a study focusing on the 
impact of trade openness on economic growth in the region. So far, the research findings on the impact of trade openness on economic growth in ASEAN countries have been very limited. These few studies found a significant effect of trade openness on economic growth (Das \& Paul, 2011; Mahmoodi \& Mahmoodi, 2016; Srinivasan, Kalaivani, \& Ibrahim, 2011). However, most of these studies applied dynamic econometrics without exploring the pattern of effects of independent variables on economic growth, which potentially remain the weakness of the results. Therefore, the important challenge of this study is the examination of the effects of trade openness on economic growth by adopting an asymmetric approach. This research intends to fill in this gap by analyzing the impact of trade openness and other economic variables on economic growth based on the data of selected ASEAN countries. This research may contribute to the literature in the area of international economics focusing on the asymmetric effects of trade openness on economic growth and policy implementation regarding this issue. This research may be useful for other countries in developing international trade policies to optimize their economic growth rate. The rest of the paper is organized as follows. Section 1 presents a brief related literature review. While section 2 introduces data and methodology, section 3 focuses on empirical findings and discussion. Finally, section 4 concludes and summarizes the main findings.

\section{Related Literature}

The neoclassical growth models state that longrun economic growth depends on the labor force and technological factors. One of the models is the widely known Cobb-Douglas production function of the form $Y=A L^{\alpha} K^{\beta}$, where total output $(Y)$ depends on labor input $(L)$ capital input, and technology or total factor productivity (A). Meanwhile, other variables such as trade openness, foreign direct investment, and domestic financial development tend to have short-run effects on output. Trade openness and free trade have been debated in recent years (Alvarado et al., 2017; Hye et al., 2016; lyke, 2017; Shayanewako, 2018). It is argued that not only does trade openness serve as an important factor in economic development. It also likely promotes economic growth in several ways. While trade openness likely increases investments as a result of enlarged market spillovers, it may also contribute to economic growth through an increase in technology transfer and domestic competition (Olabisi \& Lau, 2016).

Some previous papers have intensively examined the relationship between trade openness as well as other economic variables on economic growth across countries in the recent years (Ali, Shan, Wang, \& Amin, 2018; Bajwa \& Siddiqi, 2011; Rafat, 2018). Generally, these studies highlight that trade openness positively affects economic growth. Few papers even note the existence of a bidirectional relationship between trade openness and economic growth (Olabisi \& Lau, 2016; Shayanewako, 2018). Some empirical findings show that trade openness has a causal relationship with economic growth in some countries (Altaee \& Al-Jafari, 2014; Bajwa \& Siddiqi, 2011). A strong positive impact of trade openness on economic growth across countries is also revealed in several papers (Das \& Paul, 2011; Majeed, 2010; Malefane, 2018; Taleb, 2018). However, Bajwa and Siddiqi, (2011) state that in the long run, trade openness has a negative impact on economic growth in selected South Asian Countries. In addition, other studies also mention the relevance and significance of foreign direct investment, capital formation, and human resource in promoting economic growth (Ali et al., 2018; Rafat, 2018; Srinivasan et al., 2011). Moreover, Tab. 1 presents the summary of main literatures focusing on the effect of trade opennes on economic growth.

Regarding the impact of foreign direct investment (FDI) on economic growth, previous studies present different results (Ali et al., 2018; Alvarado, Iñiguez, \& Ponce, 2017; Ansar, Naim, \& Yaqoob, 2017; Comes, Bunduchi, Vasile, \& Stefan, 2018; Habibi \& Karimi, 2017; Mahmoodi \& Mahmoodi, 2016). The main findings of the papers reveal a strong relationship between FDI and economic growth. While some of them found a causality relationship between FDI and economic growth in several countries (Mahmoodi \& Mahmoodi, 2016; Srinivasan et al., 2011), other papers support the notion that FDI leads to economic growth or FDIeconomic growth proposition (Ogbokor, 2018; Yiew \& Lau, 2018). A recent study conducted by Ali et al. (2018) confirmed the significant effect of foreign direct investment, gross domestic investment, and life expectancy ratio as a proxy 


\section{Tab. 1: Summary of the literature review}

\begin{tabular}{|c|c|c|c|c|}
\hline Authors & $\begin{array}{l}\text { Analyzed } \\
\text { countries }\end{array}$ & $\begin{array}{c}\text { Analyzed } \\
\text { period }\end{array}$ & $\begin{array}{l}\text { Applied } \\
\text { methods }\end{array}$ & Results \\
\hline (Malefane, 2018) & South Africa & 1975-2014 & $\begin{array}{l}\text { Autoregressive } \\
\text { distributed lag } \\
\text { (ADL) bounds } \\
\text { testing approach }\end{array}$ & $\begin{array}{l}\text { Trade openness has a positive and } \\
\text { significant impact on economic growth } \\
\text { when the ratio of total trade to GDP is } \\
\text { used as a proxy. The results suggest that } \\
\text { the promotion of policies that support } \\
\text { international trade is relevant in the } \\
\text { economy. }\end{array}$ \\
\hline (lyke, 2017) & $\begin{array}{l}17 \text { Central and } \\
\text { Eastern European } \\
\text { (CEE) countries }\end{array}$ & 1994-2014 & $\begin{array}{l}\text { Panel data } \\
\text { regression } \\
\text { method }\end{array}$ & $\begin{array}{l}\text { Trade openness is important for growth } \\
\text { within the CEE countries. The results } \\
\text { show that increases in trade openness are } \\
\text { associated with increases in real GDP per } \\
\text { capita growth within these countries. }\end{array}$ \\
\hline (Olabisi \& Lau, 2016) & $\begin{array}{l}\text { Sub-Saharan } \\
\text { Africa (SSA) } \\
\text { countries }\end{array}$ & $1980-2016$ & $\begin{array}{l}\text { Cointegration, } \\
\text { Common } \\
\text { correlated effect } \\
\text { mean group } \\
\text { (CCEMG), and } \\
\text { Causality test }\end{array}$ & $\begin{array}{l}\text { A bidirectional causal relationship exists } \\
\text { among trade openness, foreign direct } \\
\text { investment net inflows, and economic } \\
\text { growth for Gambia, Senegal and South } \\
\text { African countries. The SSA government } \\
\text { should promote trade openness by } \\
\text { reducing or eliminating trade tariffs and } \\
\text { non-tariffs that can limit the economic } \\
\text { activities in the region. }\end{array}$ \\
\hline $\begin{array}{l}\text { (Mahmoodi \& } \\
\text { Mahmoodi, 2016) }\end{array}$ & $\begin{array}{l}8 \text { European } \\
\text { developing } \\
\text { countries and } 8 \\
\text { Asian developing } \\
\text { countries }\end{array}$ & 1986-2013 & $\begin{array}{l}\text { VECM causality } \\
\text { test }\end{array}$ & $\begin{array}{l}\text { The empirical results indicate long-run } \\
\text { bidirectional causality between exports } \\
\text { and economic growth of the two regions. } \\
\text { Moreover, Asian developing countries } \\
\text { experienced higher economic growth by } \\
\text { increasing exports of goods and services. }\end{array}$ \\
\hline $\begin{array}{l}\text { (Altaee \& Al-Jafari, } \\
\text { 2014) }\end{array}$ & $\begin{array}{l}\text { Kingdom } \\
\text { of Bahrain }\end{array}$ & 1980-2012 & $\begin{array}{l}\text { Vector error } \\
\text { correction model } \\
\text { (VECM) }\end{array}$ & $\begin{array}{l}\text { Trade openness is an important element } \\
\text { in determining economic growth in Bahrain. } \\
\text { The government of the country should } \\
\text { promote international trade to achieve } \\
\text { an optimum level of its economic growth. }\end{array}$ \\
\hline (Hassen et al., 2013) & Tunisia & $1975-2010$ & $\begin{array}{l}\text { Multiple } \\
\text { regression }\end{array}$ & $\begin{array}{l}\text { Trade openness has long-term positive and } \\
\text { significant effects on economic growth in } \\
\text { Tunisia. }\end{array}$ \\
\hline (Das \& Paul, 2011) & $\begin{array}{l}12 \text { top } \\
\text { performed in Asian } \\
\text { countries }\end{array}$ & 1971-2009 & \begin{tabular}{|l|} 
The system GMM \\
technique
\end{tabular} & $\begin{array}{l}\text { Trade openness has a strong positive effect } \\
\text { on economic growth in emerging Asian } \\
\text { economies. }\end{array}$ \\
\hline (Majeed, 2010) & 18 Asian countries & $1970-2007$ & $\begin{array}{l}\text { The panel data } \\
\text { regression } \\
\text { method }\end{array}$ & $\begin{array}{l}\text { The openness to trade has a significant } \\
\text { effect on economic growth in this region. }\end{array}$ \\
\hline
\end{tabular}

of human capital on the economic growth model in the case of China. The relationship between foreign direct investment and economic growth is asymmetric, implying that China's government might have been concerned about foreign direct investment. The positive effects of FDI on economic growth implies that capital inflows have generated economic activities. However, Alvarado et al. (2017) revealed the negative effects of FDI on economic growth in the lower and middle-income countries in Latin America. It means that FDI has failed to adopt 
a new technology and generate productive sectors. Therefore, foreign direct investment is inadequate to accelerate economic growth in developing countries.

Similar to FDI, domestic investment or capital formation also plays an important role in supporting economic growth. Some papers examined the impact of gross capital formation as well as domestic credit on economic growth in various cases (Mohamed, Singh, \& Liew, 2013; Sirag, SidAhmed, \& Ali, 2018; Altaee \& Al-Jafari, 2014). Most of these studies found significant effects of capital formation on economic growth. It could be highlighted that economic growth strongly depends on domestic investment. It is in line with traditional neoclassical theory, which states that investment is the main factor of economic growth. The capital accumulation which is used to increase the production capacity in the country leads to higher economic growth.

Some papers have intensively examined the effect of human capital on economic growth in recent years (Ali et al., 2018; Alvarado, Iñiguez, \& Ponce, 2017). Most of these studies conclude that human resources quality is an important determinant of economic growth across countries. The impact of human capital on economic growth is part of the endogenous growth theory. Ali et al. (2018) found the significant role of human capital, measured using the life expectancy rate, on economic growth in China. Vedia-Jerez and Chasco (2016) also discovered that human capital has a positive impact on economic growth in the long term. Human resources tend to generate economic activities through the knowledgebased economy channel. The improvement in human resources quality, indicated by more skilled and educated labors, will drive higher economic growth (Rafat, 2018). Another study conducted by Hassen et al. (2013) also confirmed that educated human resources are an important factor in economic growth. The other human capital indicator such as life expectancy, positively affects the income per capita in developed and developing countries (Butkiewicz \& Yanikkaya, 2011). Based on these reasons, this study involves the life expectancy variable as one of important factors in the analysis of economic growth.

\section{Data and Methodology \\ 2.1 Data Description}

This research focuses on the examination of the effects of trade openness and other economic variables, namely foreign direct investment, gross capital formation, and life expectancy rate on economic growth in selected ASEAN countries. The selected countries include Indonesia, Malaysia, the Philipines, Thailand, and Singapore, which together account for more than $80 \%$ of the total GDP in the regional economy. The analysis of the empirical models is based on annual time series data for the period of 1970-2017. All the data are collected from annual reports of the World Development Indicators (https://data.worldbank.org). The description of the examined variables is presented in Tab. 2. The time-series data of trade openness are presented in Fig. 1.

\subsection{Model Specification}

The neoclassical theory of growth states that capital and human resource are the main sources of long term economic growth. The economic growth model may be formulated in a standard Cobb-Douglas production function that also involves other economic variables

\section{Tab. 2: Data description}

\begin{tabular}{l|l|c}
\multicolumn{1}{c|}{ Variables } & \multicolumn{1}{c}{ Definition } & Unit \\
\hline Economic growth & Annual GDP growth at a constant price $(2010=100)$ & $\%$ \\
\hline Trade openness & $\begin{array}{l}\text { The total volume of export and imports of goods and } \\
\text { services }\end{array}$ & $\%$ of GDP \\
\hline Foreign direct investment & Net inflows of foreign direct investment & $\%$ of GDP \\
\hline Gross capital formation & Gross fixed the capital formation & $\%$ of GDP \\
\hline Life expectancy rate & Life expectancy at birth & Years \\
\hline
\end{tabular}




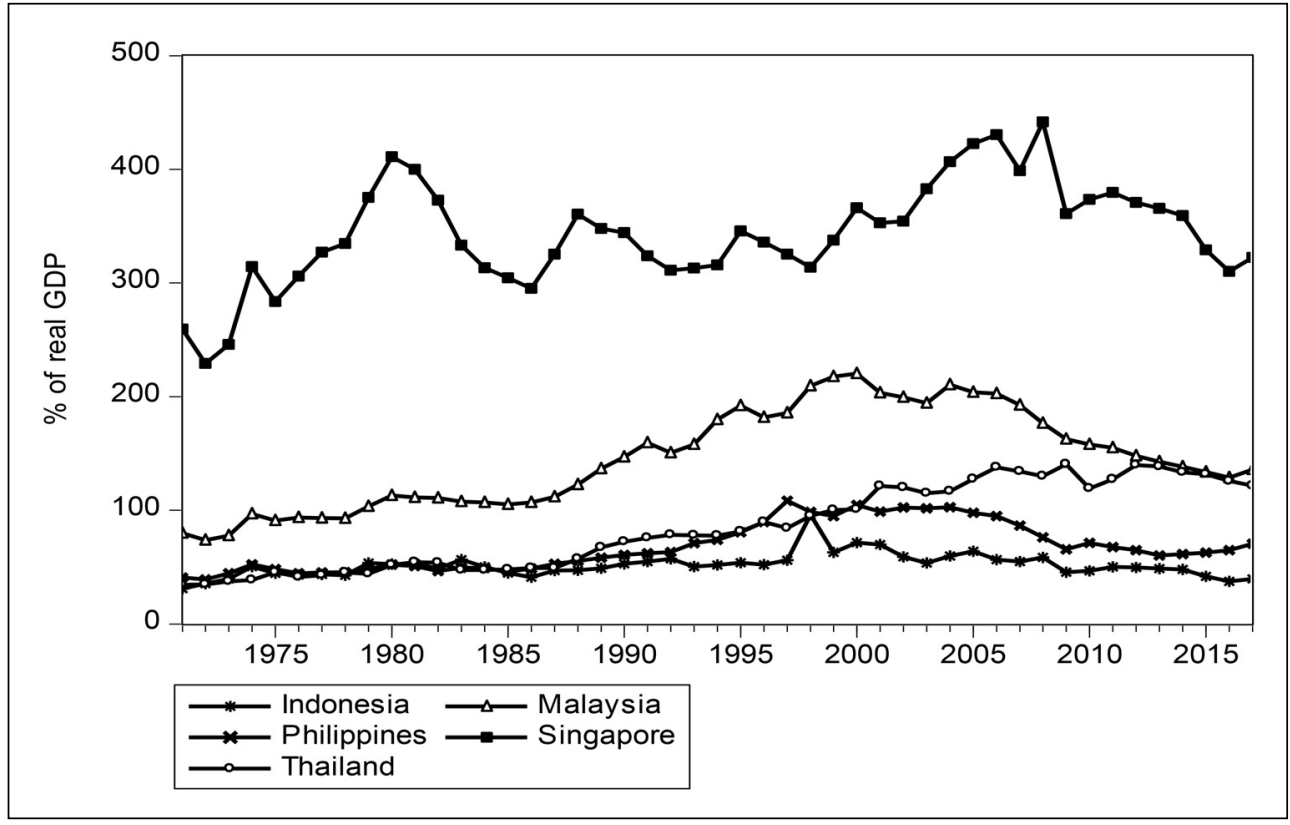

Source: World Development Indicators (https://data.worldbank.org)

such as technology level and international factors. In some recent studies, the application of neoclassical theory is extended into various models which capture some variables associated with the internal and external factors of the economy (Ali et al., 2018; Altaee \& AlJafari, 2014; Alvarado et al., 2017; Habibi \& Karimi, 2017; Rafat, 2018). Therefore, this study assumes that economic growth is a function of capital, labour, and other economic factors. More specifically, the economic growth model based on the time series data is formulated as follows:

$$
e g_{t}=F\left(K_{t}, L_{t}, Z_{t}\right)
$$

The dependent variable $e g_{t}$ is a country's real economic growth rate in period $t . K_{t}$ and $L_{t}$ are capital and human resource respectively in period $t$. Variable $Z_{t}$ represents a set of other variables related to economic growth such as trade openness and foreign direct investment. It follows that economic growth $\left(e g_{t}\right)$ is a function of some independent variables, namely trade openness $\left(\right.$ top $\left._{t}\right)$, foreign direct investment $\left(f d i_{t}\right)$, gross capital formation $\left(g c f_{t}\right)$ and life expectancy rate $\left(\right.$ ler $\left._{t}\right)$. The theoretical model is formulated in Formula (2).

$$
e g_{t}=f\left(t o p_{t}, f d i_{t}, g c f_{t}, l e r_{t}\right)
$$

\subsection{Estimation Framework}

The analysis of asymmetric effects of an economic variable on economic growth is part of a dynamic econometric model that also takes account of the long-run relationship. Therefore, the cointegration approach is an appropriate method to examine the long-run relationship between economic growth and other variables. This study utilizes an Autoregressive Distributed Lag (ARDL) model which has been widely applied in previous studies for small samples (Pesaran, Shin, \& Smith, 2001). The ARDL model may be applied to a set of variables with different orders of integration. In this analysis, the relationship between trade openness $\left(\right.$ top $\left._{t}\right)$ 
and economic growth $\left(e g_{t}\right)$ is formulated in the formula of linear ARDL of order ( $p, q)$ as follows:

$$
\begin{aligned}
& e g_{t}=\alpha_{0}+\alpha_{1} e g_{t-1}+\ldots+\alpha_{p} e g_{p}+ \\
& +\vartheta_{1} \operatorname{top}_{t-1}+\ldots+\vartheta_{q} \operatorname{top}_{q}+\varepsilon_{1 t} \\
& \operatorname{top}_{t}=\beta_{0}+\beta_{1} \operatorname{top}_{t-1}+\ldots+\beta_{p} \operatorname{top}_{p}+ \\
& +\delta_{1} e g_{t-1}+\ldots+\delta_{q} e g_{q}+\varepsilon_{2 t}
\end{aligned}
$$

where $\alpha, \delta, \beta$, and $\vartheta$ are unknown parameters. The $\varepsilon_{t}$ is the error term assumed to be serially uncorrelated with zero means and constant variance and covariance. This assumption is under the stationary condition and implies a stable long-run relationship between $e g_{t}$ and top $_{t}$. In other form, cointegration formulas for the case of the ARDL $\left(p_{1}, q_{1}\right)$, are expressed as:

$$
\begin{aligned}
& \Delta e g_{t}=\eta_{0 i}+\lambda_{1} e g_{t-1}+\lambda_{2} \operatorname{top}_{t-1}+ \\
& +\sum_{i=1}^{p} \alpha_{i} \Delta e g_{t-1}+\sum_{i=1}^{q} \alpha_{1} \Delta t o p_{t-i}+v_{t} \\
& \Delta t o p_{t}=\eta_{0 i}+\lambda_{1} \operatorname{top}_{t-1}+\lambda_{2} e g_{t-1}+ \\
& +\sum^{q} \alpha_{1} \Delta t o p_{t-i}+\sum^{p} \alpha_{i} \Delta e g_{t-1}+\mu_{t}
\end{aligned}
$$

The $\Delta$ means first difference, while $e g_{t}$ and $t o p_{t}$ are assumed to be the $I(d)$ variables. As usual, $v_{t}$ and $\mu_{t}$ are serially uncorrelated error terms with zero means and constant variance and covariance. The optimum lag length $(k)$ of the formulas is determined by information criteria such as Schwarz criterion (SC). The presence of a long-run relationship or cointegration between $e g_{t}$ and $t_{0 p}$ is represented by coefficient $\lambda_{i}$ Meanwhile, the coefficients $\alpha_{i}$ express the short-run effects of trade openness on economic growth and vice versa. Test on the presence of a cointegrating relationship between $e g_{t}$ and $t o p_{t}$ may be conducted using a standard Bound test. The null hypothesis of no cointegrating relationship is stated by $H_{0}: \lambda_{1}=\lambda_{2}=0$. Meanwhile, the alternate hypothesis which assumes the presence of cointegration is $H_{a}: \lambda_{1} \neq \lambda_{2} \neq 0$. The standard F-statistic is applied to test the joint null hypothesis that the coefficients of the lagged variables $\left(\lambda_{i}\right)$ are zero. If the computed F-statistic is greater than the upper bound critical value, then the $H_{0}$ is rejected, and the variables $e g_{t}$ and $t o p_{t}$ are cointegrated. If the F-statistic is less than the lower bound critical value, then the $H_{0}$ cannot be rejected.

This study emphasizes the asymmetric effects of trade openness on economic growth. Most previous studies analyzed the effect of trade openness on economic growth under the linear relationship assumption. In this case, the empirical models fail to distinguish the effect of increasing and reducing trade openness on economic growth. Therefore, the asymmetric approach is relevant to present such effects in this study. We use a standard Nonlinear Autoregressive Distributed Lag (NARDL) model to explore the asymmetric effects of trade openness on economic growth. According to Shin, Yu and Greenwood-Nimmo (2014), the asymmetric NARDL model captures the partial sum of decompositions in constructing the long-run relationship between dependent and independent variables. This technique allows distinguishing between linear and nonlinear cointegration, which is different from the standard ARDL that presume symmetric or linear effects of the regressor on a dependent variable. Therefore, we begin by formulating the long-run relationship between $e_{t}$ and $t o p_{t}$ as the following asymmetric regression:

$$
e g_{t}=\phi^{+}{ } o p_{t}^{+}+\phi^{-} t o p_{t}^{-}+v_{t}
$$

Formula (7) presents the effects of partial decompositions of trade openness $\left(\right.$ top $_{t}^{+}$ and $t o p_{t}^{-}$) on economic growth with $v_{t}$ as the error term. The coefficient $\phi^{+}$and $\phi^{-}$are the parameters which assume the presence of an asymmetric relationship between trade openness and economic growth. The components of the partial sum of positive $\left(\right.$ top $\left._{t}^{+}\right)$and negative $\left(\right.$ top $\left._{t}^{-}\right)$changes are defined as follows:

$$
\begin{aligned}
& \text { top }_{t}^{+}=\sum_{i=1}^{t} \Delta \text { top }_{i}^{+}=\sum_{i=1}^{t} \max \left(\text { top }_{i}, 0\right) \\
& \text { top }_{t}^{-}=\sum_{i=1}^{t} \Delta t o p_{i}^{-}=\sum_{i=1}^{t} \min \left(\text { top }_{i}, 0\right)
\end{aligned}
$$


Following Shin, Yu and Greenwood-Nimmo (2014), we formulate the asymmetric error correction model relating to the formula (5) in $\operatorname{NARDL}(p, q)$ model is as follows:

$$
\begin{aligned}
& \Delta e g_{t}=\alpha_{0}+\rho e g_{t-1}+\theta^{+} \operatorname{top}_{t-1}^{+}+ \\
& +\theta^{-} t o p_{t-1}^{-}+\sum_{j=1}^{p} \omega_{j} \Delta e g_{t-j}+ \\
& +\sum_{j=0}^{q}\left(\pi_{j}^{+} \Delta t o p_{t-j}^{+}+\pi_{j}^{-} \Delta t o p_{t-j}^{-}\right)+\varepsilon_{t}
\end{aligned}
$$

This research estimates the empirical model of economic growth as a function of some variables as mentioned in Formula (2). Therefore, the complete estimated formula is formulated as follows:

$$
\begin{aligned}
& \Delta e g_{t}=\alpha_{0}+\rho e g_{t-1}+\theta^{+} \operatorname{top}_{t-1}^{+}+ \\
& +\theta^{-} \operatorname{top}_{t-1}^{-}+\varphi_{1} f d i_{t}+\varphi_{2} g c f_{t}+\varphi_{3} \text { ler }_{t}+ \\
& +\sum_{j=1}^{p} \omega_{j} \Delta e g_{t-j}+\sum_{j=0}^{p} \psi_{j} \Delta f d i_{t-j}+ \\
& +\sum_{j=0}^{p} \eta_{j} \Delta g c f_{t-j}+\sum_{j=0}^{p} \gamma_{j} \Delta l e r_{t-j}+ \\
& +\sum_{j=0}^{q}\left(\pi_{j}^{+} \Delta t o p_{t-j}^{+}+\pi_{j}^{-} \Delta t o p_{t-j}^{-}\right)+\varepsilon_{t}
\end{aligned}
$$

Formula (11) exhibits asymmetric effects of trade openness on economic growth. The formula also presents the dynamic relationship between foreign direct investment, gross capital formation, life expectancy rate, and economic growth. This study examines the dynamic effects of the number of economic variables and components of positive and negative changes in trade openness on economic growth. The coefficients $\theta^{+}=-\rho \phi^{+}$and $\theta^{-}=-\rho \phi^{-}$, meanwhile $\varepsilon_{t}$ is the error term. The optimum lag length of $\mathrm{p}$ and $\mathrm{q}$ are determined using information criteria such as Schwarz criterion (SC).

Regarding the effects of trade openness on economic growth as expressed in formula (11), three possibilities of asymmetric effects may occur in the model. The empirical model contains only long-run asymmetric effects, or only short-run asymmetric effects, or both the long and short-run asymmetric relationship. Therefore, we should conduct the evaluation of the presence of long and the short-run asymmetric effects of trade openness variable on economic growth. The standard Wald restriction test may be applied for these purposes. In the first step, we test the hypothesis of a long-run symmetry using the null hypothesis statement as $H_{0}: \theta^{+}=\theta^{-}$. The null hypothesis is rejected if the F-statistic is significant implying the presence of longrun asymmetric effects of trade openness on economic growth. The second step is the testing on the possible existence of asymmetric effects of trade openness on economic growth in the short-run. The null hypothesis of symmetric effects is stated as $H_{0}: \sum_{j=0}^{q} \pi_{j}^{+}=\sum_{j=0}^{q} \pi_{j}^{-}$. The null hypothesis is rejected if the F-computed is over its critical values. Therefore, rejecting both null hypotheses implies that the effects of trade openness on economic growth are symmetric both in the long and short runs.

The presence of asymmetric models leads to the possibility of calculating the multiplier effects of each partial component of trade openness, which measures the adjustment process from short-run disequilibrium to its longrun equilibrium. The asymmetric cumulative dynamic multipliers of the positive and negative components of trade openness are calculated using formula as follows:

$$
\begin{aligned}
& d m_{k}^{+}=\sum_{j=0}^{k} \frac{\delta\left(e g_{t+j}\right)}{\delta\left(\operatorname{top}_{t}^{+}\right)}, k=0,1,2 \ldots . . \\
& d m_{k}^{-}=\sum_{j=0}^{k} \frac{\delta\left(e g_{t+j}\right)}{\delta\left(\operatorname{top}_{t}^{-}\right)}, k=0,1,2 \ldots . .
\end{aligned}
$$

The parameter $d m_{k}^{+}$and $d m_{k}^{-}$are multiplier effects of positive and negative components of trade openness. As a number of $\mathrm{k}$ increases, the value of these multipliers tends to be higher and equal to the asymmetric long-run coefficients $\phi^{+}$and $\phi^{-}$respectively.

\section{Empirical Results and Discussion}

The dynamic econometric methodology, including the ARDL model, requires a stationary test of the data, even though the model may be applied to the set of variables with a different order of integration. The standard approach of Augmented DickeyFuller (ADF) is used to conduct the unit root test of the variables for which the results are presented in Tab. 3. We applied the ADF test based on the empirical model with intercept and the optimal lag 


\section{Tab. 3: Results of the unit root test}

\begin{tabular}{c|c|c|c|c|c} 
Variables & Indonesia & Philippines & Thailand & Singapore & Malaysia \\
\hline $\mathrm{eg}_{\mathrm{t}}$ & $-5.13[0.00]$ & $-3.77[0.01]$ & $-4.13[0.00]$ & $-5.09[0.00]$ & $-5.68[0.00]$ \\
\hline $\mathrm{top}_{\mathrm{t}}$ & $-3.49[0.01]$ & $-1.62[0.46]$ & $-0.53[0.87]$ & $-1.93[0.31]$ & $-1.44[0.55]$ \\
\hline $\mathrm{fdi}_{\mathrm{t}}$ & $-2.29[0.18]$ & $-2.91[0.06]$ & $-3.16[0.03]$ & $-3.25[0.02]$ & $-3.56[0.02]$ \\
\hline $\mathrm{gcf}_{\mathrm{t}}$ & $-1.81[0.37]$ & $-2.83[0.06]$ & $-2.26[0.18]$ & $-1.52[0.51]$ & $-2.36[0.15]$ \\
\hline $\mathrm{ler}_{\mathrm{t}}$ & $-1.58[0.48]$ & $-2.14[0.22]$ & $-1.60[0.47]$ & $-2.06[0.25]$ & $-3.54[0.01]$ \\
\hline$\Delta \mathrm{eg}_{\mathrm{t}}$ & $-8.21[0.00]$ & $-7.72[0.00]$ & $-7.72[0.00]$ & $-9.10[0.00]$ & $-9.10[0.00]$ \\
\hline$\Delta \mathrm{top}_{\mathrm{t}}$ & $-10.15[0.00]$ & $-6.05[0.00]$ & $-8.06[0.00]$ & $-7.60[0.00]$ & $-4.89[0.00]$ \\
\hline$\Delta \mathrm{fdi}_{\mathrm{t}}$ & $-5.39[0.00]$ & $-9.70[0.00]$ & $-9.41[0.00]$ & $-8.93[0.00]$ & $-7.70[0.00]$ \\
\hline$\Delta \mathrm{gcf}_{\mathrm{t}}$ & $-5.29[0.00]$ & $-5.66[0.00]$ & $-6.31[0.00]$ & $-8.41[0.00]$ & $-6.39[0.00]$ \\
\hline$\Delta \mathrm{ler}_{\mathrm{t}}$ & $-3.05[0.00]$ & $-3.20[0.00]$ & $-3.09[0.03]$ & $-4.05[0.00]$ & $-6.04[0.00]$ \\
\hline
\end{tabular}

Source: own

Note: The values in the parenthesis are a probability. The optimum lag length based on the Schwartz Criterion (SC). All the first difference data series are stationary

length based on Schwartz Criterion. The results show that the variables are of a different degree of integration and none of them has a unit root at the first difference. According to Pesaran, Shin and Smith (2001), the fact that the examined variables have a different order of integration makes it proper to apply the ARDL model for the analysis.

As part of the dynamic analysis approach, we should conduct the cointegration test on the set of the variables before estimating the NARDL model. For that purpose, the standard Bound test procedure was applied and the results are presented in the lower panel of Tab. 4 and Tab. 5. The F-statistic for all countries rejects the null hypothesis of no cointegrating relationship even at 5 percent level of significance. Therefore, we accept the presence of a long-run relationship in the set of variables that include economic growth, trade openness, foreign direct investment, gross capital formation, and life expectancy rate. The next step is to estimate the empirical NARDL based on formula (11) for each country. We present the results of the individual estimation of each country in Tab. 4 (Indonesia, Philippines, and Singapore) and in Tab. 5 (Thailand and Malaysia). The final estimates are the best models following the general-to-specific approach of ARDL by choosing the optimum lag length based on Schwartz Criterion.
The focus of the analysis in this paper is on elaborating the long run and short-run asymmetric effects of trade openness on economic growth. The coefficients $\theta^{+}$and $\theta^{-}$in formula (11) indicate the possibility of the presence of long-run effects of the positive and negative changes in trade openness on economic growth. On the other hand, the coefficients $\pi_{i}^{+}$and $\pi_{i}^{-}$, also in formula (11), represent the possibility of the existence of short-run asymmetric effects of positive and negative changes in trade openness on economic growth. The estimation results show that the coefficient $\theta^{+}$for Philippines and Singapore are positive and statistically significant even at 1 percent level, indicating that the increase of trade openness leads to higher economic growth. The estimated same coefficient for the case of Thailand is negative and significant, implying that the increase of trade openness did not contribute to the higher economic growth. A different result is found for the case of Malaysia where the same coefficient is found to be not statistically significant even at 10 percent level of significance. As for the coefficient $\theta^{-}$, which indicates the effect of decreased trade openness on economic growth, the estimated results for all countries are not statistically significant, implying that the decrease in trade openness did not lower economic growth.

Turning to the short-run effects, the coefficient of positive changes $\left(\pi_{i}^{+}\right)$and negative 
changes $\left(\pi_{i}^{-}\right)$in trade openness show different results among the five countries. The estimated coefficient $\pi_{1}^{+}$is positive but insignificant, even at the 10 percent level, for the Philippines and Malaysia. The estimated results for Thailand and Singapore are negative and also insignificant. However, we found that the coefficient $\pi_{1}^{+}$is negative and significant at 1 percent level for the case of Indonesia, implying that the increasing trade openness reduces economic growth rate. Similarly, the result for the coefficient $\pi_{1}^{-}$which indicates the effect of negative changes in trade openness on economic growth, is positive and significant only for Indonesia, indicating that the negative changes of trade openness cause lower economic growth only in Indonesia.

\section{Tab. 4: Results of ARDL Estimates for Indonesia, Philippines and Singapore}

\begin{tabular}{|c|c|c|c|c|c|c|}
\hline \multirow{3}{*}{$\begin{array}{l}\text { Independent } \\
\text { variables }\end{array}$} & \multicolumn{6}{|c|}{ Dependent variable: Economic growth $\left(\mathrm{eg}_{\mathrm{t}}\right)$} \\
\hline & \multicolumn{2}{|c|}{ Indonesia } & \multicolumn{2}{|c|}{ Philippines } & \multicolumn{2}{|c|}{ Singapore } \\
\hline & Coefficient & P-value & Coefficient & P-value & Coefficient & P-value \\
\hline Constant & -98.343 & $0.004^{* * *}$ & 129.761 & $0.025^{\star *}$ & 283.543 & $0.079^{*}$ \\
\hline$e_{t-1}$ & -1.657 & $0.000^{\star \star *}$ & -0.738 & $0.000^{\star * *}$ & -1.442 & $0.000^{* * *}$ \\
\hline top $_{t-1}^{+}$ & -0.029 & 0.651 & 0.094 & $0.067^{*}$ & 0.099 & $0.031^{* *}$ \\
\hline top $_{\mathrm{t}-1}^{-}$ & -0.031 & 0.640 & -0.014 & 0.624 & 0.017 & 0.583 \\
\hline $\mathrm{fdi}_{\mathrm{t}-1}$ & 0.081 & 0.832 & 1.392 & $0.052^{* *}$ & -0.292 & 0.115 \\
\hline$g_{\mathrm{cf}} \mathrm{t}_{\mathrm{f}}$ & -0.132 & 0.344 & -0.229 & 0.184 & -0.415 & $0.012^{* *}$ \\
\hline $\operatorname{ler}_{t-1}$ & 1.508 & $0.005^{\star \star \star}$ & -1.969 & $0.032^{\star \star}$ & -3.660 & 0.118 \\
\hline$\Delta \mathrm{eg}_{\mathrm{t}-1}$ & 0.331 & $0.007^{* * *}$ & 0.108 & 0.437 & 0.282 & $0.037^{* *}$ \\
\hline$\Delta \mathrm{fdi}_{\mathrm{t}}$ & 0.494 & 0.160 & 0.533 & 0.320 & 0.165 & $0.095^{*}$ \\
\hline$\Delta \mathrm{fdi}_{\mathrm{t}-1}$ & 0.412 & 0.215 & & & 0.283 & $0.011^{* * *}$ \\
\hline$\Delta \mathrm{gcf}_{\mathrm{t}}$ & 0.169 & 0.307 & 0.404 & $0.020^{\star *}$ & 0.286 & $0.070^{*}$ \\
\hline$\Delta \mathrm{gcf}_{\mathrm{t}-1}$ & 0.439 & $0.004^{* * *}$ & & & 0.279 & 0.124 \\
\hline$\Delta l e r_{t}$ & 10.265 & 0.256 & -10.921 & $0.099^{*}$ & -11.973 & $0.004^{* * *}$ \\
\hline$\Delta l e r_{t-1}$ & 42.520 & $0.034^{* *}$ & & & -7.767 & $0.056^{\star *}$ \\
\hline$\Delta$ top $^{+}$ & -0.414 & $0.000^{* * *}$ & 0.076 & 0.517 & -0.042 & 0.312 \\
\hline$\Delta$ top $_{\mathrm{t}-1}^{+}$ & -0.045 & 0.630 & -0.180 & 0.156 & 0.002 & 0.940 \\
\hline$\Delta$ top & 0.154 & $0.053^{* *}$ & 0.263 & 0.108 & 0.061 & 0.109 \\
\hline$\Delta \mathrm{top}_{\mathrm{t}-1}^{-}$ & 0.037 & 0.592 & -0.027 & 0.853 & -0.050 & 0.128 \\
\hline R-squared & \multicolumn{2}{|c|}{0.972} & \multicolumn{2}{|c|}{0.74} & \multicolumn{2}{|c|}{0.887} \\
\hline Schwarz criterion & \multicolumn{2}{|c|}{3.911} & \multicolumn{2}{|c|}{5.09} & \multicolumn{2}{|c|}{5.376} \\
\hline F-statistic & \multicolumn{2}{|c|}{$35.314^{* \star *}$} & \multicolumn{2}{|c|}{$5.55^{\star \star \star}$} & \multicolumn{2}{|c|}{$11.641^{* \star \star}$} \\
\hline Bound test & \multicolumn{2}{|c|}{ F-statistic: $19.82^{* * *}$} & \multicolumn{2}{|c|}{ F-statistic: $6.45^{\star \star *}$} & \multicolumn{2}{|c|}{ F-statistic: $8.080^{* * *}$} \\
\hline $\begin{array}{l}\text { Short-run } \\
\text { symmetry test }\end{array}$ & \multicolumn{2}{|c|}{ F-statistic: $11.86^{* * *}$} & \multicolumn{2}{|c|}{ F-statistic: 2.06} & \multicolumn{2}{|c|}{ F-statistic: 1.252} \\
\hline $\begin{array}{l}\text { Long-run } \\
\text { symmetry test }\end{array}$ & \multicolumn{2}{|c|}{ F-statistic: 0.002} & \multicolumn{2}{|c|}{ F-statistic: $3.78^{* * *}$} & \multicolumn{2}{|c|}{ F-statistic: $3.364^{* *}$} \\
\hline
\end{tabular}


The important aspect of the NARDL analysis is determining the effect pattern of trade openness on economic growth in each country. Therefore, in line with the focus of this study, we investigate the possibility of asymmetric effects of trade openness on economic growth by applying the Waldrestriction test procedure. While the restriction test for the long-run symmetry was imposed on the coefficients $\theta^{+}$and $\theta^{-}$the restriction test for the short-run symmetry is imposed on the coefficients $\pi^{+}$and $\pi^{-}$. The results of the test for both long run and short run symmetry for all countries are presented in the lower panel of Tab. 4 and Tab. 5. The conclusion of these tests is summarized in Tab. 6 . The short-run effects of trade openness on economic growth are symmetric for all countries, except Indonesia. In those four countries, the increase in trade openness leads to higher economic growth, while the decrease in trade openness reduces the economic growth in the short-run time. As for the long-run effects, trade openness has asymmetric effects on economic growth in three countries, namely the Philippines, Singapore, and Thailand. Meanwhile, trade openness has symmetric effects on economic growth in the other two countries, namely Indonesia and Malaysia. It implies that the increased value of export and import lead to higher economic growth in the long run, but the reduced value of export and import does not reduce economic growth in the former three countries. In contrast, for the latter two countries, the higher the trade openness cause the higher the economic growth, and the lower the trade openness, the lower the economic growth in the long run.

This study also examines the effects of FDI, gross capital formation, and human capital on economic growth. The estimation results show that while FDI is an important factor of economic growth only in the Philippines and Singapore, gross capital formation affects economic growth in all five countries. Moreover, human capital, proxied by life expectancy rate, has a positive and significant effect on economic growth only in Indonesia and Thailand. Meanwhile, it has a negative effect on economic growth in the other three countries. It may suggest that the longer the life of the population in these three countries the higher the burden of the economy. This phenomenon is quite similar to the case of China where longer life expectancy is associated with lower economic growth
(Ali et al., 2018). However, the results of this study confirm the neoclassical theory, which states that the economic variables such as investment, human resources, and international trade determine economic growth rate (Habibi \& Karimi, 2017; Rafat, 2018).

The results of the error correction estimation from the ARDL model which contain asymmetric and symmetric effects in the long and shortrun are presented in Tab. 7 and Tab. 8. The estimation process followed the conclusion of the model evaluation for each country as presented in Tab. 6. For the case of Indonesia, the short-run asymmetric effects of trade openness changes on changes in economic growth are indicated by the coefficients of $\Delta t o p_{t}^{+}$and $\Delta t o p_{t}^{-}$. The coefficient of $\Delta t o p_{t}^{+}$is negative and significant, implying that the positive changes in trade openness do not increase economic growth, while the coefficient $\Delta t o p_{t}^{-}$is positive, implying that negative changes in trade openness do reduce economic growth. In contrast, the effect of trade openness on economic growth in the long-run is symmetric, indicated by the coefficient of $t o p_{t}$. This implies that in the long run, both positive and negative changes in export and import did not affect economic growth rate.

The three countries including the Philippines, Thailand, and Singapore have similar results regarding the effects of trade openness changes on economic growth, namely asymmetric in the long-run and symmetric in the short-run. More specifically, the coefficient top ${ }_{t}^{+}$is positive and significant for the case of the Philippines and Singapore, indicating that their economic growth gained positive benefits from the increase in their exports and imports. The coefficient $\Delta t o p_{t}^{-}$is negative indicating that the decrease in trade openness relates to the increase of economic growth. In contrast, Thailand shows different results where both the coefficients of $t o p_{t}^{+}$and $\Delta t o p_{t}^{-}$are negative and statistically significant at 10 percent. It implies that the positive changes in export and import failed to increase economic growth in the short-run. Meanwhile, the negative changes in trade openness are associated with higher economic growth in the short run. In the long-run, the coefficient $t o p_{t}^{+}$is negative and statistically significant indicating that the increase of trade openness has a significant relationship with the decreasing of economic growth. The case of Malaysia provides extreme results where there is no impact of trade 


\section{Tab. 5: $\quad$ Results of ARDL Estimates for Thailand and Malaysia}

\begin{tabular}{|c|c|c|c|c|}
\hline \multirow{3}{*}{ Independent variables } & \multicolumn{4}{|c|}{ Dependent variable: Economic growth $\left(\mathrm{eg}_{\mathrm{t}}\right)$} \\
\hline & \multicolumn{2}{|c|}{ Thailand } & \multicolumn{2}{|c|}{ Malaysia } \\
\hline & Coefficient & P-value & Coefficient & P-value \\
\hline Constant & -76.884 & $0.019^{* *}$ & 123.764 & $0.018^{* *}$ \\
\hline $\mathrm{eg}_{\mathrm{t}-1}$ & -0.261 & 0.382 & -1.453 & $0.000^{\star * *}$ \\
\hline top ${ }_{t-1}^{+}$ & -0.098 & $0.070^{*}$ & 0.017 & 0.435 \\
\hline top $_{\mathrm{t}-1}^{-}$ & 0.083 & 0.421 & -0.028 & 0.234 \\
\hline $\mathrm{fdi}_{\mathrm{t}-1}$ & -0.683 & 0.393 & 0.319 & 0.367 \\
\hline $\operatorname{gcf}_{t-1}$ & -0.528 & $0.004^{* * *}$ & 0.237 & $0.061^{*}$ \\
\hline $\operatorname{ler}_{t-1}$ & 1.532 & $0.007^{* * *}$ & -1.735 & $0.023^{\star *}$ \\
\hline$\Delta e g_{t-1}$ & -0.361 & 0.114 & 0.2491 & $0.068^{*}$ \\
\hline$\Delta \mathrm{fdi}_{\mathrm{t}}$ & -0.504 & 0.419 & 0.341 & 0.313 \\
\hline$\Delta \mathrm{gcf}_{\mathrm{t}}$ & -0.450 & 0.140 & 0.789 & $0.000^{* * *}$ \\
\hline$\Delta \mathrm{gcf}_{\mathrm{t}-1}$ & & & -0.065 & 0.659 \\
\hline$\Delta$ ler $_{\mathrm{t}}$ & -2.417 & 0.507 & -18.65 & 0.189 \\
\hline$\Delta$ top $^{+}$ & -0.107 & 0.504 & 0.032 & 0.655 \\
\hline$\Delta$ top- & -0.059 & 0.756 & -0.099 & 0.477 \\
\hline R-squared & \multicolumn{2}{|c|}{0.589} & \multicolumn{2}{|c|}{0.815} \\
\hline Schwarz criterion & \multicolumn{2}{|c|}{5.871} & \multicolumn{2}{|c|}{5.358} \\
\hline F-statistic & \multicolumn{2}{|c|}{$2.525^{\star \star}$} & \multicolumn{2}{|c|}{$11.185^{\star \star *}$} \\
\hline Bound test & \multicolumn{2}{|c|}{ F-statistic: $3.987^{\star \star}$} & \multicolumn{2}{|c|}{ F-statistic: $22.681^{* * *}$} \\
\hline Short-run symmetry test & \multicolumn{2}{|c|}{ F-statistic: 0.032} & \multicolumn{2}{|c|}{ F-statistic: 0.751} \\
\hline Long-run symmetry test & \multicolumn{2}{|c|}{ F-statistic: $4.942^{* * *}$} & \multicolumn{2}{|c|}{ F-statistic: 1.488} \\
\hline
\end{tabular}

Source: own

Note: The results are based on ARDL cointegrating and long-run estimation with the optimum lag length of one lag based on Schwarz Criterion (SC). ${ }^{*},{ }^{* *},{ }^{* * *}$ indicate significant at $10 \%, 5 \%$ and $1 \%$ significance levels, respectively.

\section{Tab. 6: The effects of trade openness on economic growth}

\begin{tabular}{l|c|c|c|c|c}
\multicolumn{1}{c|}{ Indicators } & Indonesia & Philipines & Thailand & Singapore & Malaysia \\
\hline Cointegration relationship & Yes & Yes & Yes & Yes & Yes \\
\hline Short-run effects & Asymmetry & Symmetry & Symmetry & Symmetry & Symmetry \\
\hline Long run effects & Symmetry & Asymmetry & Asymmetry & Asymmetry & Symmetry \\
\hline
\end{tabular}

Source: own

Note: The conclusions are summarized based on the estimation results presented in Tab. 4 and Tab. 5 . 
openness on economic growth both in the short and long runs. However, the relationship between positive and negative changes in trade openness and economic growth is symmetric.

Regarding the role of trade openness on economic growth, the findings of this study are in line with the recent literature across countries (Bajwa \& Siddiqi, 2011; Das \& Paul, 2011; Hye et al., 2016; Shayanewako, 2018). The similarity mainly concerns the positive effects of trade openness on economic growth. The contrast is that while the findings of this research assume asymmetrical effects, the findings of the previous studies mostly assume symmetrical effects. Arguably the results of this research have more practical relevance than the previous ones since the real effects of movements in variables on other variables are mostly asymmetric. The relevance and significant impact of FDI on economic growth in the ASEAN region is also similar to the previous findings in some cases (Ali et al., 2018; Alvarado et al., 2017; Mahmoodi \& Mahmoodi, 2016). Meanwhile, the significant impact of gross capital formation on economic growth confirms the previous research (Mohamed et al., 2013; Sirag et al., 2018). Moreover, the human capital, proxied by life expectancy rate, that is found to have a strong positive impact on economic growth is also supported by recent literature (Ali et al., 2018; Vedia-Jerez \& Chasco, 2016). We may conclude that this study confirms the neoclassical growth models in accepting the relationship between trade openness, FDI, and human capital and economic growth. This paper contributes to the current literature by incorporating the asymmetric effects of trade openness on economic growth. While the Philippines, Singapore, and Thailand have experienced long-run asymmetric effects of trade openness on economic growth, Indonesia has had asymmetric effects in the short-run. Accordingly, the central governments in the ASEAN countries should formulate appropriate policies to minimize the negative impacts of this issue.

Finally, the next step is to present the dynamic multipliers of the effect of trade

\section{Tab. 7: Asymmetric and symmetric effects in Indonesia, the Philippines and Singapore}

\begin{tabular}{|c|c|c|c|c|c|c|}
\hline \multirow{3}{*}{$\begin{array}{l}\text { Independent } \\
\text { variables }\end{array}$} & \multicolumn{6}{|c|}{ Dependent variable: Change of economic growth $\left(\Delta \mathrm{eg}_{\mathrm{t}}\right)$} \\
\hline & \multicolumn{2}{|c|}{ Indonesia } & \multicolumn{2}{|c|}{ Philippines } & \multicolumn{2}{|c|}{ Singapore } \\
\hline & Coefficient & P-value & Coefficient & P-value & Coefficient & P-value \\
\hline \multicolumn{7}{|l|}{ Short-run effects } \\
\hline$\Delta$ top $_{\mathrm{t}}$ & & & 0.088 & 0.182 & 0.006 & 0.632 \\
\hline$\Delta$ top $_{\mathrm{t}}^{+}$ & -0.492 & $0.000^{* * *}$ & & & & \\
\hline$\Delta$ top $_{\mathrm{t}}^{-}$ & 0.318 & $0.000^{* \star *}$ & & & & \\
\hline$\Delta \mathrm{fdi}_{\mathrm{t}}$ & 0.195 & 0.543 & 0.013 & 0.979 & 0.295 & $0.010^{* * *}$ \\
\hline$\Delta \mathrm{gcf}_{\mathrm{t}}$ & 0.221 & 0.299 & 0.351 & $0.037^{* *}$ & 0.378 & $0.020^{* *}$ \\
\hline$\Delta$ ler $_{\mathrm{t}}$ & 0.356 & 0.420 & -16.136 & $0.007^{\star \star \star}$ & -6.885 & 0.110 \\
\hline CointEq(-1) & -1.193 & $0.000^{* * *}$ & -0.751 & $0.000^{* * *}$ & -0.850 & $0.000^{* * *}$ \\
\hline \multicolumn{7}{|l|}{ Long-run effects } \\
\hline top $_{t}$ & -0.054 & 0.631 & & & & \\
\hline top $_{t}^{+}$ & & & 0.136 & $0.060^{*}$ & 0.105 & $0.020^{* *}$ \\
\hline top- & & & -0.043 & 0.210 & -0.043 & 0.145 \\
\hline $\mathrm{fdi}_{\mathrm{t}}$ & -0.092 & 0.882 & 1.680 & $0.080^{*}$ & 0.144 & 0.378 \\
\hline $\mathrm{gcf}_{\mathrm{t}}$ & 0.112 & 0.643 & -0.511 & $0.066^{*}$ & -0.305 & $0.065^{\star}$ \\
\hline $\operatorname{ler}_{t}$ & 0.854 & 0.204 & -3.323 & $0.021^{* *}$ & -5.749 & $0.011^{\text {*** }}$ \\
\hline Constant & -59.233 & 0.144 & 223.072 & $0.016^{* *}$ & 404.930 & $0.009^{* * *}$ \\
\hline
\end{tabular}


Asymmetric and symmetric effects in Thailand and Malaysia

\begin{tabular}{|c|c|c|c|c|}
\hline \multirow{3}{*}{$\begin{array}{c}\text { Independent } \\
\text { variables }\end{array}$} & \multicolumn{4}{|c|}{ Dependent variable: Change of economic growth $\left(\Delta \mathrm{eg}_{\mathrm{t}}\right)$} \\
\hline & \multicolumn{2}{|c|}{ Thailand } & \multicolumn{2}{|c|}{ Malaysia } \\
\hline & Coefficient & P-value & Coefficient & P-value \\
\hline \multicolumn{5}{|l|}{ Short-run effects } \\
\hline$\Delta$ top $_{\mathrm{t}}$ & -0.076 & $0.031^{* *}$ & 0.003 & 0.766 \\
\hline \multicolumn{5}{|l|}{$\Delta$ top $_{t}^{+}$} \\
\hline \multicolumn{5}{|l|}{$\Delta$ top $_{\mathrm{t}}^{-}$} \\
\hline$\Delta \mathrm{fdi}_{\mathrm{t}}$ & 0.245 & 0.565 & 0.307 & 0.296 \\
\hline$\Delta \mathrm{gcf}_{\mathrm{t}}$ & -0.208 & $0.021^{* *}$ & 0.669 & $0.000^{\star * \star}$ \\
\hline$\Delta l \mathrm{ler}_{\mathrm{t}}$ & 0.388 & 0.177 & -0.333 & $0.061^{*}$ \\
\hline CointEq(-1) & -0.411 & $0.010^{* * *}$ & -1.111 & $0.000^{* * *}$ \\
\hline \multicolumn{5}{|l|}{ Long-run effects } \\
\hline top $_{t}$ & & & 0.003 & 0.767 \\
\hline top $_{t}^{+}$ & -0.146 & $0.104^{*}$ & & \\
\hline top $_{t}^{-}$ & 0.035 & 0.822 & & \\
\hline $\mathrm{fdi}_{\mathrm{t}}$ & -0.336 & 0.746 & 0.277 & 0.301 \\
\hline $\mathrm{gcf}_{\mathrm{t}}$ & -0.575 & $0.069^{*}$ & 0.072 & 0.323 \\
\hline $\operatorname{ler}_{\mathrm{t}}$ & 1.574 & $0.078^{*}$ & -0.300 & $0.058^{* *}$ \\
\hline Constant & -73.245 & 0.145 & 24.023 & $0.022^{* *}$ \\
\hline
\end{tabular}

Source: own estimation based on the error correction model

openness on economic growth for all countries except Malaysia. Since the estimated effects of trade openness on economic growth for Malaysia is symmetric both in the long and short runs, the NARDL estimation does not provide the dynamic multiplier effects. As presented in Fig. 2 , the dynamic effects of positive and negative changes of trade openness on economic growth for the Phillippines and Singapore show positive accumulation, indicated by the asymmetry lines above the horizontal axis. In other words, these two countries gain a positive net impact of trade openness on economic growth. An asymmetric effect of trade openness on economic growth appears to last for two years, after which trade openness turns to have an asymmetric effect on economic growth. It might be the case that especially Singapore is a small open economy that heavily relies on, and has to gain from international trade in both directions, increased and decreased openness. The estimated net positive gain that lasts for two years is only a rough estimate, assuming one time positive and negative shocks to trade openness. In reality such shocks might occur repeatedly, and isolating one from another is impossible, and therefore the net positive gain likely lasts for more than two years. Focusing on Indonesia and Thailand, the two countries experienced a negative net impact of trade openness on economic growth in the long run. More specifically, Thailand has the highest negative effect of trade openness on economic growth among the ASEAN countries. These contrasting results might be attributable to different structures and the size of the economies. Among the five countries, arguably the economies of Singapore and the Philippines are of the smallest size but in terms of trade openness Singapore is the highest, more than one and half of its GDP, while the remaining four countries having trade openness less than 100 percent, with Indonesia and the Philippines as least open economies. 


\section{Fig. 2: Dynamic multiplier of trade openness on economic growth}

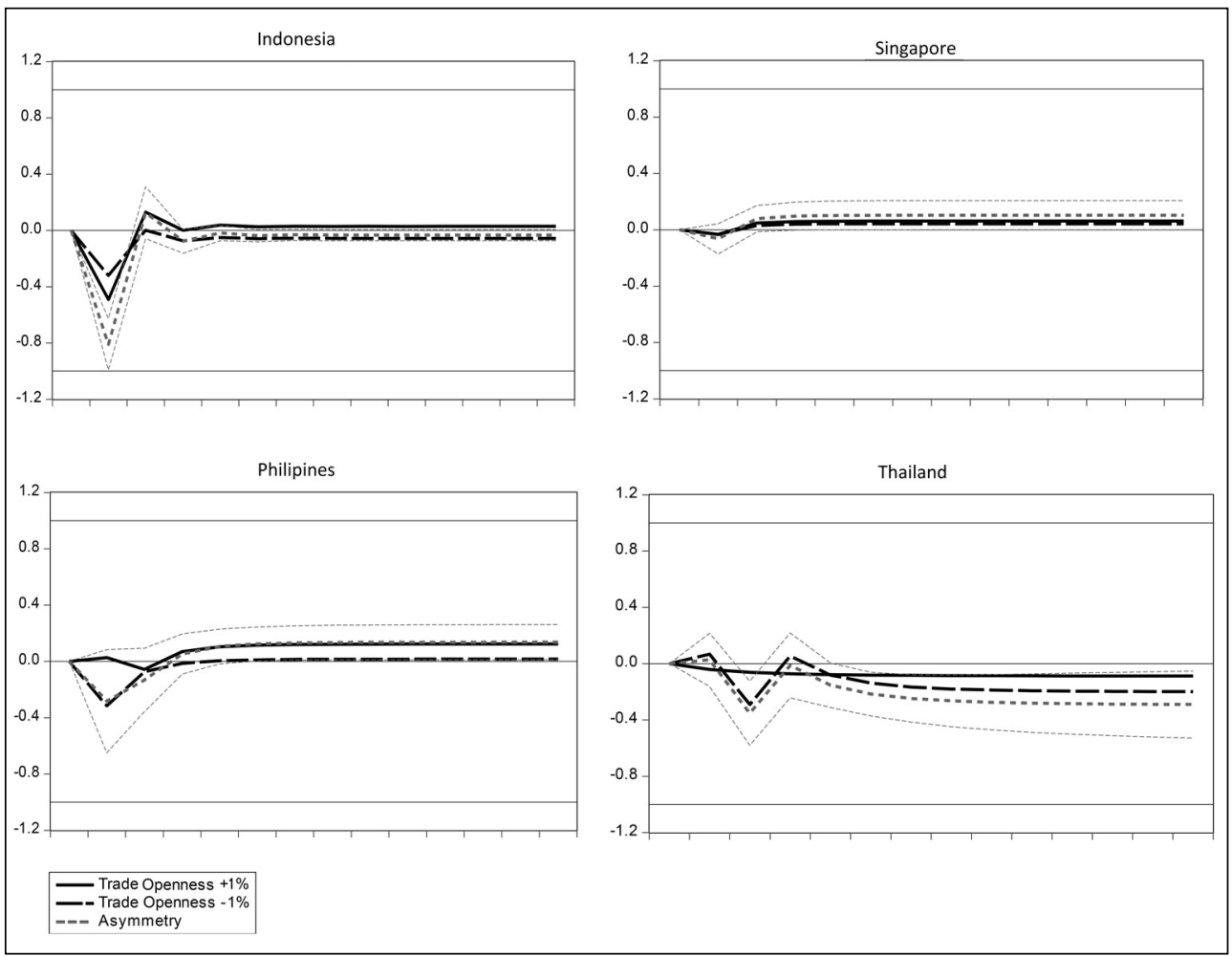

Source: own

\section{Conclusion}

This research examines the effects of trade openness and other economic variables on economic growth in selected ASEAN countries. Using annual data, the empirical NARDL models present asymmetric effects of trade openness on economic growth in Indonesia, Philippines, Thailand, and Singapore. Meanwhile, such effects for the case of Malaysia are symmetric both in the short and long runs. The trade openness has asymmetric effects in the long run and symmetric effects in the short-run for the Philippines, Thailand, and Singapore. The results are different for Indonesia where the impact of trade openness is asymmetric in the short run and symmetric in the long run. This paper highlights that trade openness has a positive impact on economic growth only in the Philippines and Singapore.
It implies that most of the ASEAN countries face a challenge regarding the implementation of trade liberalization. It suggests that the governments in this region take advantage of trade liberalization by boosting exports and imports to maintain economic growth as an important indicator of macroeconomic performance at a desirable level. Further, as for Singapore and the Philippines whether the trade openness increases or decreases economic growth tends to increase, while the remaining three countries have to make sure that trade openness constantly increases, since the decline in growth due to decreased trade openness outweighs the increased growth resulting from the increased trade openness. The results of this study contribute to the literature of international economics by providing new insight into the asymmetric effects of trade openness on economic growth. 
The relevance and significant role of FDI in driving economic growth in ASEAN countries may mean that financial mobility in that region is an important factor of economic growth. As part of the openness variable, FDI has contributed to generating economic growth. The domestic investment, represented by gross capital formation, also affects economic growth in ASEAN countries. It implies that financial development should be encouraged in these countries. Similarly, human capital, which is proxied by life expectancy rate, affects economic growth. We may conclude that the result of this study is in line with the neoclassical theory which states that the economic variables such as investment, human resources, and international trade determine economic growth rate.

Even though this study provides some valuable insight regarding the asymmetric effects of trade openness on economic growth, the limitation of our empirical model is restricted to the data of Indonesia. We examine the effects of trade openness, foreign direct investment, gross capital formation, and life expectancy ratio on economic growth. However, our empirical growth model focuses on the analysis of asymmetric effects of trade openness on economic growth. The future research may extend to the analysis of asymmetric effects of all those variables on economic growth for various countries.

Acknowledgment: The authors would like to thank The Centre for Economics Studies, the Islamic University of Indonesia, for providing the fund for this research under the scheme of Applied Research Grant No. 5/Dir.PPE/II/2019.

\section{References}

Ali, U., Shan, W., Wang, J., \& Amin, A. (2018). Outward foreign direct investment and economic growth in China: Evidence from asymmetric ARDL approach. Journal of Business Economics and Management, 19(5), 706-721. http://doi.org/10.3846/ jbem.2018.6263.

Altaee, H. H. A., \& Al-Jafari, M. K. (2014). Financial development, trade openness and economic growth: A trilateral analysis of Bahrain. International Journal of Economics and Finance, 7(1), 241-255. http://doi.org/10.5539/ ijef.v7n1p241.

Alvarado, R., Iñiguez, M., \& Ponce, P. (2017). Foreign direct investment and economic growth in Latin America. Economic Analysis and Policy, 56, 176-187. http://doi. org/10.1016/j.eap.2017.09.006.

Ansar, R., Naim, M. M., \& Yaqoob, S. (2017). Impact of FDI on economic growth: Evidence from Pakistan. Bulletin of Business and Economics, 6(3), 111-116.

Bajwa, S., \& Siddiqi, M. W. (2011). Trade openness and its effects on economic growth in selected South Asian countries: A panel data study. World Academy of Science, Engineering and Technology, 5(2), 940-945.

Butkiewicz, J. L., \& Yanikkaya, H. (2011). Institutions and the impact of government spending on growth. Journal of Applied Economics, XIV(2), 319-341. http://doi. org/10.1016/S1514-0326(11)60017-2.

Comes, C. A., Bunduchi, E., Vasile, V., \& Stefan, D. (2018). The impact of foreign direct investments and remittances on economic growth: A case study in central and eastern Europe. Sustainability (Switzerland), 10(1), 1-16. http://doi.org/10.3390/su10010238.

Das, A., \& Paul, B. P. (2011). Openness and growth in emerging Asian economies: Evidence from GMM. Economics Bulletin, 31(3), 22192228.

Habibi, F., \& Karimi, M. S. (2017). Foreign direct investment and economic growth: evidence from Iran and GCC. Iranian Economic Review, 21(3), 601-620.

Hassen, S., Anis, O., Taha, Z., \& Yosra, S. (2013). Trade openness and economic growth: The case of Tunisia. International Journal of Advances in Management and Economics, 2(2), 24-32.

Hye, Q. M. A., Wizarat, S., \& Lau, W.Y. (2016). The impact of trade openness on economic growth in China: An empirical analysis. Journal of Asian Finance, Economics and Business, 3(3), 27-37. http://doi. org/10.13106/jafeb.2016.vol3.no3.27.

lyke, B. N. (2017). Does trade openness matter for economic growth in the CEE countries? Review of Economic Perspectives, 17(1), 3-24. http://doi.org/10.1515/revecp-2017-0001.

Mahmoodi, M., \& Mahmoodi, E. (2016). Foreign direct investment, exports and economic growth: Evidence from two panels of developing countries. Economic ResearchEkonomska Istrazivanja, 29(1), 938-949. http://doi.org/10.1080/1331677X.2016.1164922.

Majeed, M. T. (2010). Inequality, trade openness and economic growth in Asia. Applied 
Econometrics and International Development, 10(2), 201-212.

Malefane, M. R. (2018). Impact of trade openness on economic growth: Empirical evidence from South Africa. International Economics, 71(4), 387-416.

Maria, R. S., Urata, S., \& Intal, P. S. J. (2017). The ASEAN Economic Community Into 2025 and Beyond (Vol. 5). Manila, Philippines: Economic Research Institute.

Mohamed, M. R., Singh, K. S. J., \& Liew, C.-Y. (2013). Impact of foreign direct investment \& domestic investment on economic growth of Malaysia. Malaysian Journal of Economic Studies, 50(1), 21-35. http://doi.org/10.21511/ ppm.14(2-2).2016.04.

Nagyová, L'., Horáková, M., Moroz, S., Horská, E., \& Poláková, Z. (2018). The analysis of export trade between Ukraine and Visegrad countries. E\&M Economics and Management, 21(2), 115-132. http://doi.org/10.15240/ tul/001/2018-2-008.

Ogbokor, C. A. (2018). Foreign direct investment and economic progress: Application of a dynamic model. International Journal of Economics and Finance Studies, 10(1), 1-15.

Olabisi, O. E., \& Lau, E. (2016). Causality testing between trade openness, foreign direct investment and economic growth: Fresh evidence from sub-Saharan African countries. International Economics, 71(4), 437-464.

Paudel, R. (2014). Trade liberalization and economic growth in developing countries: Does stage of development matter? (Research Paper No. 14-13). Canberra: Crawford School of Public Policy.

Pesaran, M. H., Shin, Y., \& Smith, R. J. (2001). Bounds testing approaches to the analysis of level relationships. Journal of Applied Econometrics, 16(3), 289-326. http://doi.org/10.1002/(ISSN)1099-1255.

Rafat, M. (2018). The interactive relationship between economic growth and foreign direct investments (FDI): A VAR analysis in Iran. Iranian Economic Review, 22(1), 163-185. http://doi.org/10.22059/ier.2018.65355.

Shayanewako, V. B. (2018). The relationship between trade openness and economic growth: The case of BRICS countries. Journal of Global Economics, 6(2), 6-10. http://doi. org/10.4172/2375-4389.1000289.

Shin, Y., Yu, B., \& Greenwood-Nimmo, M. (2014). Modeling asymmetric cointegration and dynamic multipliers in a nonlinear ARDL framework. In W. C. Horrace \& R. C. Sickles (Eds.), Festschrift in Honor of Peter Schmidt. New York, NY: Springer.

Sing, C. C. (2018). A Resilient and FutureReady ASEAN (in ASEAN Economic Integration Brief No. 04/November). Jakarta, Indonesia.

Sirag, A., SidAhmed, S., \& Ali, H. S. (2018). Financial development, FDI and economic growth: evidence from Sudan. International Journal of Social Economics, 45(8), 1236-1249. http://doi.org/10.1108/IJSE-10-2017-0476.

Srinivasan, P., Kalaivani, M., \& Ibrahim, P. (2011). An empirical investigation of foreign direct investment and economic growth in SAARC nations. Journal of Asia Business Studies, 5(2), 232-248. http://doi. org/10.1108/15587891111152366.

Taleb, D. (2018). The dynamic interactions among trade openness and economic growth: Evidence from Algeria. International Journal of Economic Behavior and Organization, 5(6), 162-167. http://doi.org/10.11648/j. ijebo.20170506.16.

Vedia-Jerez, D. H., \& Chasco, C. (2016). Long-run determinants of economic growth in South America. Journal of Applied Economics, 19(1), 169-192. http://doi.org/10.1016/S15140326(16)30007-1.

Yiew, T. H., \& Lau, E. (2018). Does foreign aid contribute to or impeded economic growth? Journal of International Studies, 11(3), 21-30. http://doi.org/10.14254/2071-8330.2018/11-3/2. 